\title{
The EFFects of Habitat Modification on a SPOTTED Frog PopUlation IN Yellowstone National PaRK
}

\author{
Debra A. Patla $\bullet$ Charles R. Peterson \\ DEPARTMENT OF BIOLOGICAL SCIENCES $\downarrow$ IDAHO STATE UNIVERSITY \\ POCATELLO
}

\section{$-\quad$ INTRODUCTION}

Declines and extinctions of many populations of amphibians have been noted worldwide in recent years (Corn and Fogelman 1984, Beiswenger 1986, McAllister and Leonard 1990, Wake and Morowitz 1990, Wake 1991, Adler 1992). Habitat modifications due to human activities may contribute to many of these declines. Habitat may be destroyed overtly, or it may be fragmented. Fragmentation results in reduced area, a differential loss of important habitat components, and increased isolation of populations (Wyman 1990). The persistence of amphibians in areas where modifications short of total habitat destruction occur depends on the preservation of essential habitat components and landscape connectivity that allows individual animals access to breeding, foraging, and wintering sites (Sinsch 1989). Long-term persistence also may rely on the immigration of individuals from other populations (Pechmann et al. 1991, Sjogren 1991).

Our efforts to conserve amphibian species and to establish methods of sustainable resource use depend on our understanding of habitat fragmentation and knowledge of the behavioral and population responses to different types of habitat modifications (Gibbons 1988, Groom and Schumaker 1993). Few studies have addressed these types of questions. Notable exceptions include some studies on the effects of logging (Corn and Bury 1989) and acidification (Wyman and Hawksley-Lescault 1988, Harte and Hoffman 1989, Corn and Vertucci 1992). In Europe, researchers and wildlife conservationists are investigating the impacts of roads on amphibians and attempting to find solutions to fragmentation and mortality effects (Langton 1989), but this concern has not yet received noticeable attention in North America. We lack studies evaluating the relative importance and integration of foraging areas, hibernacula, breeding sites, areas occupied pre- and post-breeding, and dispersal routes connecting these areas. With these kinds of information, researchers and land managers will acquire the ability to better analyze, predict, and mitigate the effects of habitat modifications that are sources of amphibian population declines.

\section{$\checkmark \quad$ OBJECTIVES AND APPROACH}

The goal of this project is to determine how specific habitat modifications may contribute to local changes in the abundance and distribution of amphibians. Our approach is to replicate a previous field study of a spotted frog population in Yellowstone National Park (YNP). This previous study, conducted in 1953-55 by Frederick B. Turner, provides a baseline for the population's demographic characteristics, habitat use, and movement patterns. By comparing the historic and current data, we are analyzing how the frog population and its use of habitat has changed over the 40-year period. Specifically, we seek to answer these questions:

1) In an area where site modifications due to human activities have occurred, how has frog habitat changed? 
2) Have the demographic characteristics of the frog population in the modified area changed?

3) Has the distribution of frogs in the modified area changed?

4) Have the movement patterns of frogs within the modified area changed?

5) How have changes in habitat contributed to the observed changes in the demographic characteristics and spatial relationships of this population?

\section{$\checkmark \quad$ METHODS}

\section{STUDY SPECIES}

The spotted frog Rana pretiosa is a widespread and common species in YNP. Declines of populations on the west coast, in the Great Basin, and along the Wasatch Front have led to a C1 classification under the Endangered Species Act, with listing as endangered or threatened "warranted but precluded" (USDI Fish and Wildlife Service 1993). Elsewhere in its range, including YNP, the species is classified as C2. Spotted frogs appear to be abundant and reproducing well in the Greater Yellowstone Ecosystem (Peterson et al. 1992).

Spotted frogs inhabit stream edges and marshy areas near ponds, lakes, springs, and streams. Breeding occurs mainly in temporary or permanent shallow-water ponds. In YNP, spotted frogs are slow-growing and long-lived; females reach sexual maturity in their fifth or sixth year and may live up to 12 or 13 years; males breed in their fourth year and may live up to 10 years (Turner 1960).

\section{STUDY AREA}

The Lodge Creek study area is located near Lake Lodge, approximately $1.6 \mathrm{~km}$ south of the intersection of East Entrance Road and Grand Loop Highway in YNP. Turner's 1953-55 study was concentrated in a 28 hectare area (Fig. 1A) which included two breeding pools, two springs, boggy areas, intermittent drainages, and a permanent stream, Lodge Creek (formerly known as Soldier Creek). Most features of the former study site remain recognizable in 1993 (Fig. 1B). We have expanded the current investigation to include Lodge Creek downstream from Turner's core study area to its mouth at the shore of Yellowstone Lake. The core area is included in our long-term monitoring plan (Peterson et. al. 1992).

\section{POPULATION CHARACTERISTICS AND HABITAT USE}

We have been monitoring the population of frogs in this area since 1991 (Peterson et al. 1992). In 1993, we hand-captured, marked, released, and recaptured juvenile and adult frogs approximately 5 to 6 days per week from 15 May to 21 August, and one or two days per week from 28 Aug to 22 October. Each frog was given a unique code based on a pattern of toe-clipping (Waichman 1992). We recorded the sex, length, and weight of each frog at the time of each capture/recapture. We also recorded the dates and locations of each capture/recapture and noted the key features of capture sites, including wetland type, vegetation, and water and air temperatures. These data are similar to data collected by Turner during the former study. In addition, we used radiotelemetry to follow the movements of 20 adult frogs for periods of time ranging from a few days up to 6 weeks. We monitored breeding sites and documented dates of egg deposition, hatching, tadpole development, and emergence of metamorphosing frogs. We mapped key locations and measured distances using both a Trimble Basic Plus Global Positioning System (GPS) and compassand-tape techniques. In order to create the study area map, we photographed the site from an airplane at about $600 \mathrm{~m}$., digitized the photograph, and used computer graphics software to draw the map and identify features.

We are in the process of comparing Turner's data to our data on demographic characteristics, spatial relationships, and habitat. As a first step, we are compiling our 1990 s data to perform analyses that will be similar to those used for the 1950 s data set. For this semiannual report, we quantified captures and recaptures to estimate population size, and we plotted capture/recapture locations on maps of the study area to estimate distribution and movements. At this point in our analyses of the data sets, we are able to make broad comparisons only.

Our final report will contain more detailed comparisons of the historical and current data sets, 


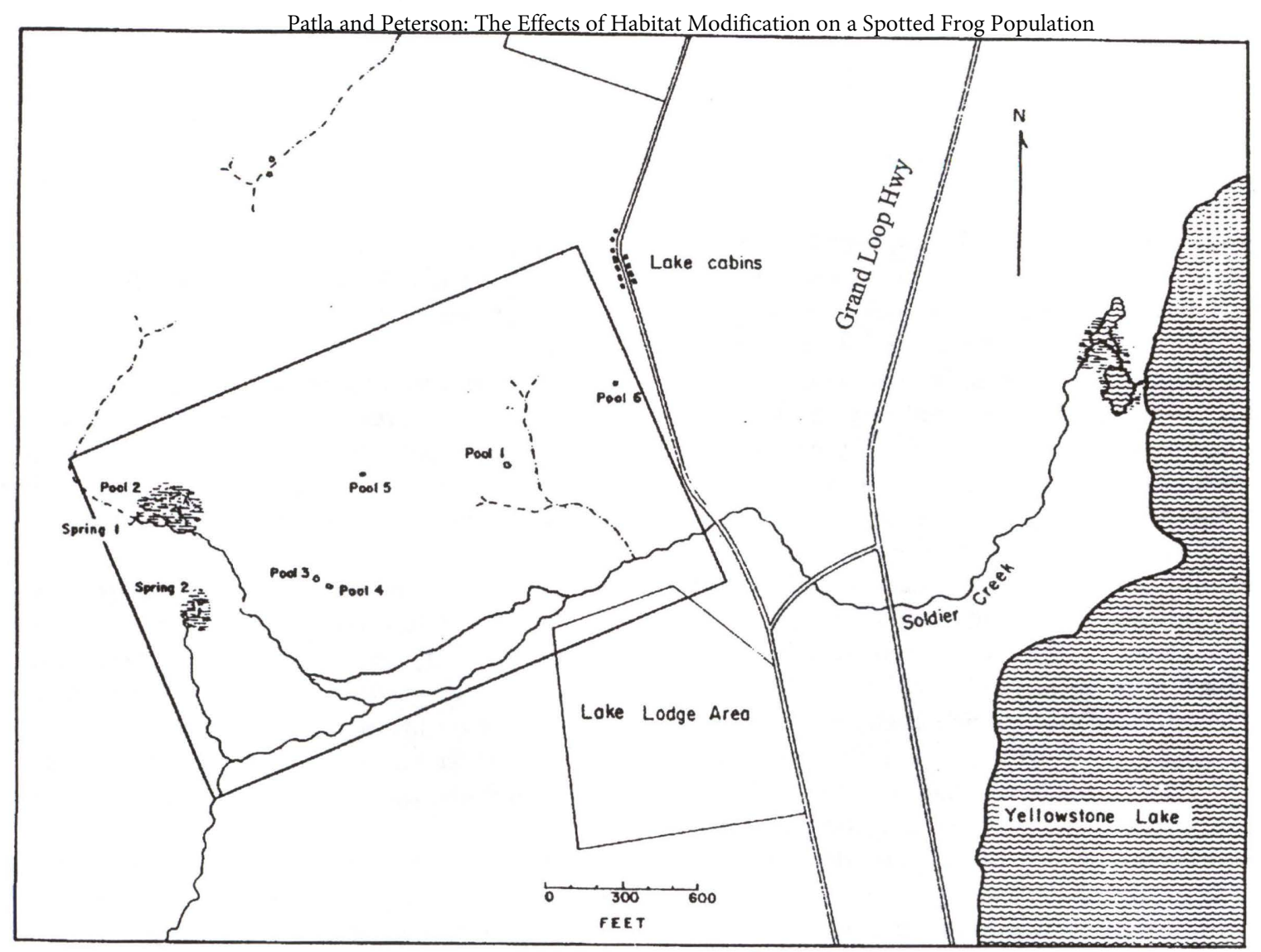

Figure 1a. F.B. Turner's Lodge Creek study area, 1953-55. The rectangle indicates the core study area. This map is a composite of figures 1 and 7 in Turner 1960.

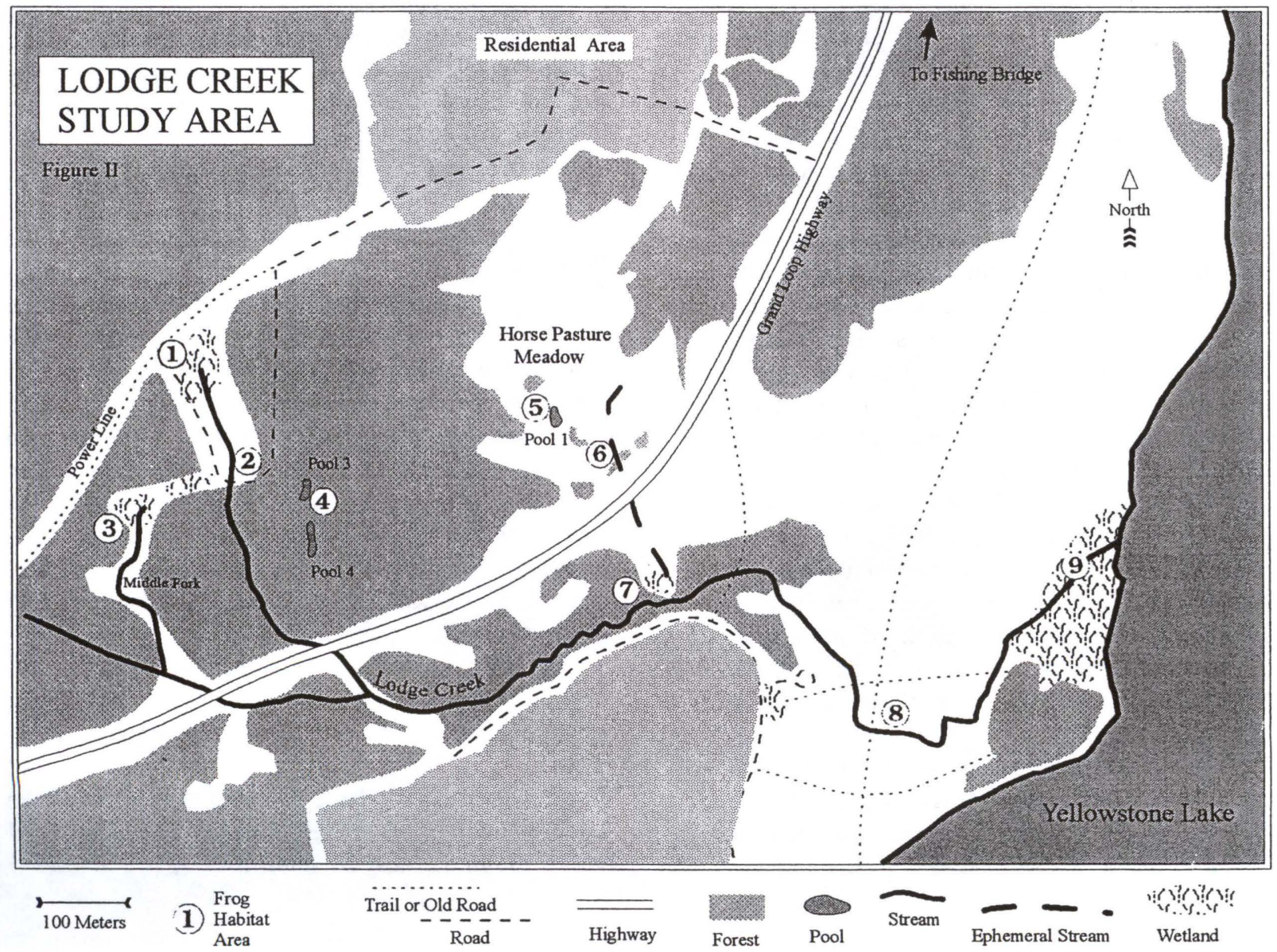

Figure 1b. Lodge Creek study area, 1993. Numbers identify key habitat areas. There are some differences the two maps that are due to discrepancies in mapping techniques. 
including comparisons of size classes, growth rates, sex ratios, larval population sizes, movement rates, and habitat use. We will refine our population estimates using the Jolly-Seber or other open population size estimation methods. Using GPS data and aerial photographs, we will enhance the study area map and create site-specific maps of portions of the study area. To gain a better understanding of how sites and habitat have changed, we will meet with YNP maintenance and archival staff and request their assistance in determining precise locations and dates of developments. Using weather data collected at Lake, we will compare temperatures and precipitation of the 10 years prior to each field study (1943-53 and 1983-93) and for the time period between the two studies. Finally, we will use the comparative demographic, movement, and habitat use data to refine our hypotheses of how specific habitat modifications may contribute to the decline or persistence of a frog population. These hypotheses will be instrumental in design of next year's field study.

\section{$\checkmark \quad$ PROJECT PROGRESS AND FINDINGS}

\section{HABITAT MODIFICATIONS}

The study area includes sites that have been modified by human activities as well as those that appear to have changed very little since the 1950 s. Turner (1960) described his study site as "subject to minimal human use"; exceptions included a foot trail used for guided walks through the area, the proximity of Lake Lodge Cabins to a short section of Lodge Creek, and the use of 45 acres as summer pasture for Park horses. Since Turner's study, there have been two major modifications of the area. The first, in the early 1970s, was the relocation of the Grand Loop Highway approximately 400 meters west-northwest from its previous route (compare Fig. 1A and 1B). The second, in the early 1980 s, was the development of the springs at the head of the main fork of Lodge Creek and associated construction of a pumping, piping and chlorination system, roads, culverts, maintenance/chlorine-treatment building, and fences.

These developments caused changes at some of the former frog habitat areas in Turner's core study area. A list of important former habitat areas, development at those sites, and descriptions of the current sites is included in Table 1; the areas are identified by number on Figure 1B. In summary, there are three major changes apparent in habitat:

1) At the time of the historical study, the area at the head of Lodge Creek's main fork included an open sedge meadow with a spring-fed pool and water-filled holes, seeps and a large boggy area. It now supports a young lodgepole stand, willows, and a restricted seep/sedge area. The former pool is gone; two water-filled holes are the only bodies of surface water deeper than a few centimeters. The seeps come together to form the head of Lodge Creek, which is undisturbed downstream of the pumping operation until it reaches the highway. Changes in hydrology and vegetation appear to be due to development of the springs and accompanying surface disturbances.

2) Within the historical core study area, there were no road or highway crossings of Lodge Creek. The new highway crosses Lodge Creek just above the confluence of the main and middle forks, and the streams pass through culverts beneath the highway. A side channel of Lodge Creek that formerly flowed north of the main channel was also crossed by the highway. This channel is now completely dry and grown with non-wetland vegetation. Other than the loss of the side channel and the addition of the highway with road shoulders and culverts, there are no apparent changes in the drainage.

3) A seasonally wet meadow at the east side of the former study area has been bisected by the highway, resulting in the probable loss of one temporary pool (pool 6) and an unknown amount of temporary wetland areas. Formerly, an ephemeral stream with two branches flowed from its origin from melting snows and spring rain in the meadow to its junction with Lodge Creek. This drainage, barely visible in tall grass and sedges, now carries water in one branch only, and passes under the highway through a culvert. The vicinity of the crossing has been filled and reconstructed with embankments on both sides of the highway.

Other habitat areas of the former study area are still present, including two breeding pools (pools 1 and 3), a non-breeding pool (pool 4), most of Lodge Creek, and the springs at the head of the middle fork. These sites appear to have changed very little in the 40-year interim. 


\begin{tabular}{|c|c|c|c|c|c|c|c|c|c|c|c|}
\hline 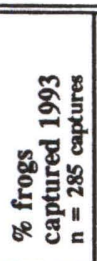 & $\begin{array}{l}\text { 局 } \\
\stackrel{m}{n}\end{array}$ & $\stackrel{\infty}{m}$ & $\begin{array}{l}\infty \\
\infty \\
\text { i }\end{array}$ & erson: The E & $\stackrel{\infty}{\infty}$ & $\overline{\mathrm{ff} \text { Habitat Mo }}$ & ification & n a Spotted Fros & Population & z & 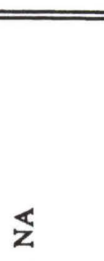 \\
\hline 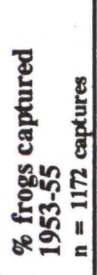 & $\stackrel{\text { of }}{\vec{n}}$ & $\underset{\dot{v}}{\dot{\theta}}$ & o̊ & $\begin{array}{l}\text { :0 } \\
\stackrel{0}{0} \\
0\end{array}$ & 占 & $\begin{array}{l}80 \\
0 \\
0 \\
0\end{array}$ & $\stackrel{\text { of }}{\stackrel{2}{*}}$ & $\begin{array}{l}\infty \\
\infty \\
\text { ని }\end{array}$ & 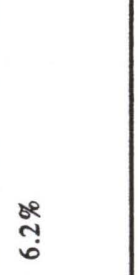 & 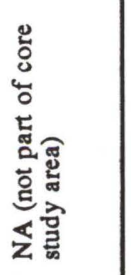 & 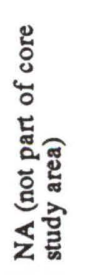 \\
\hline 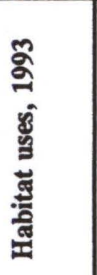 & 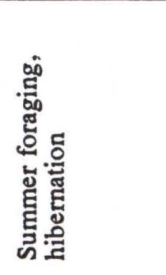 & 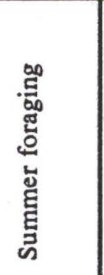 & 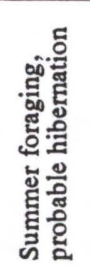 & 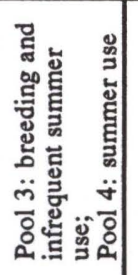 & 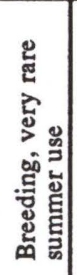 & 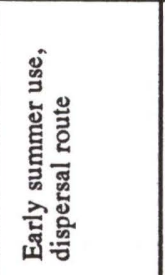 & 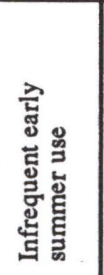 & 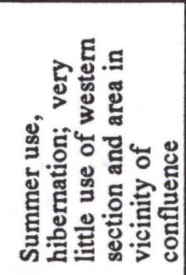 & 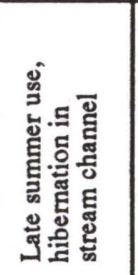 & 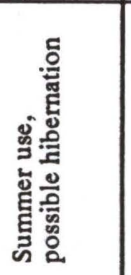 & 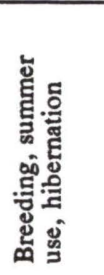 \\
\hline 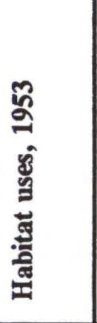 & 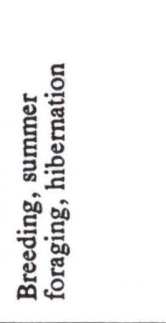 & 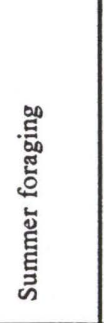 & 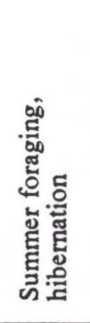 & 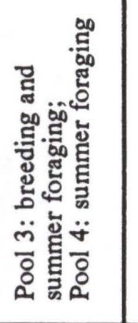 & 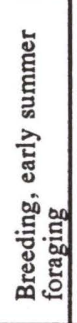 & 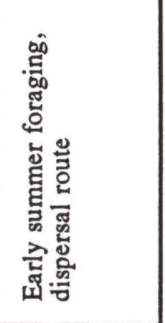 & 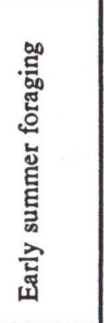 & 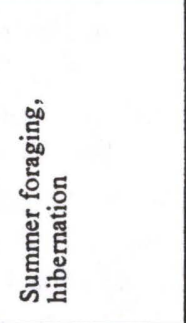 & 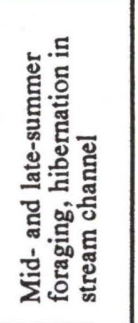 & 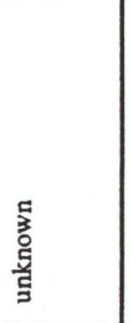 & 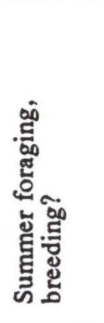 \\
\hline 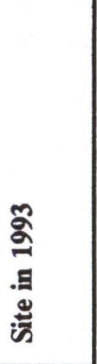 & 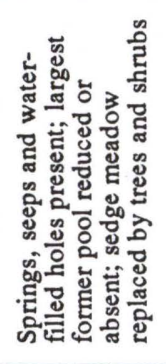 & 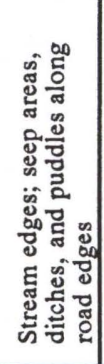 & 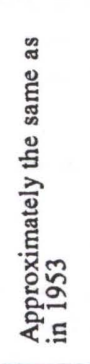 & 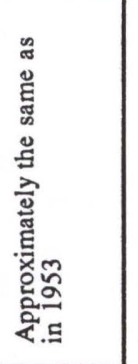 & 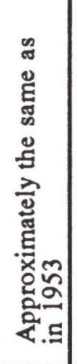 & 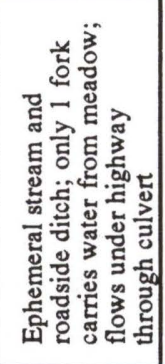 & 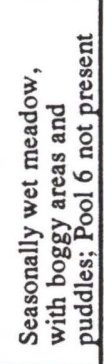 & 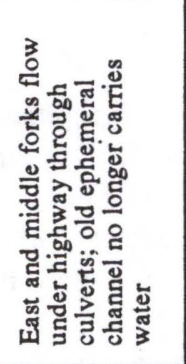 & 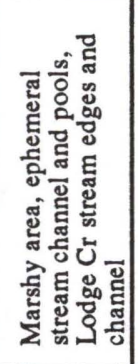 & 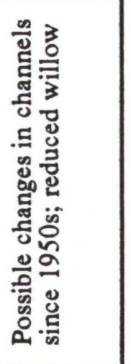 & 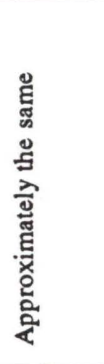 \\
\hline 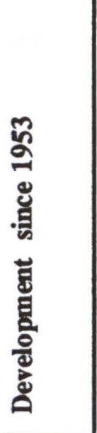 & 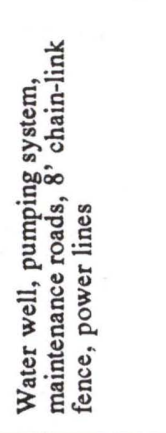 & 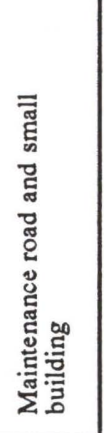 & $\begin{array}{l}\text { : } \\
\text { z }\end{array}$ & $\begin{array}{l}\text { : } \\
\text { ż }\end{array}$ & 总 & 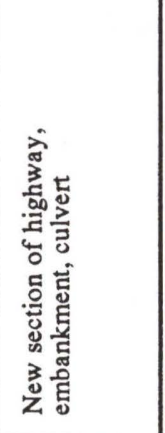 & 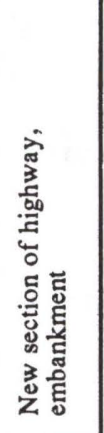 & 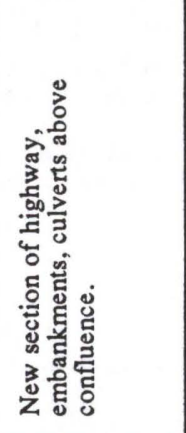 & 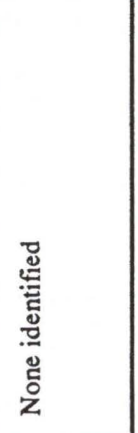 & 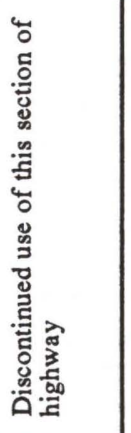 & 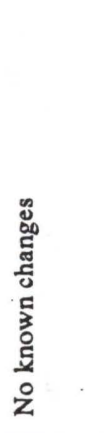 \\
\hline 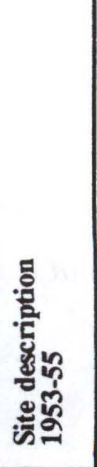 & 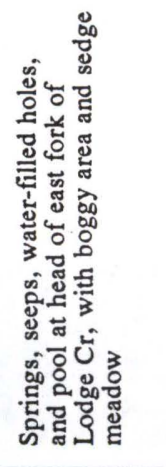 & 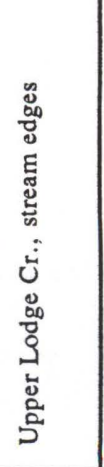 & 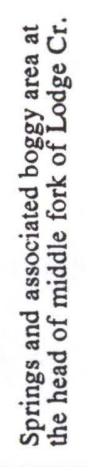 & 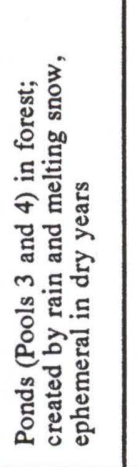 & 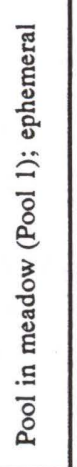 & 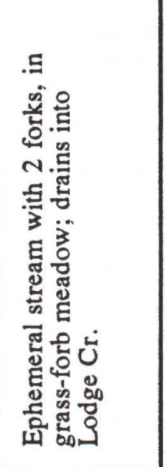 & 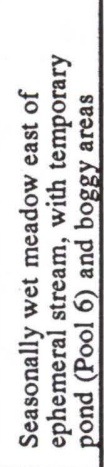 & 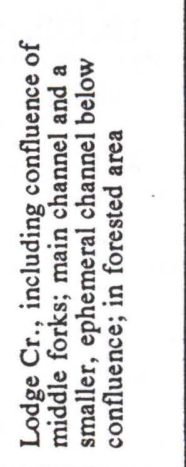 & 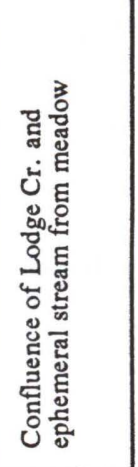 & 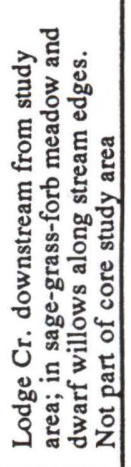 & 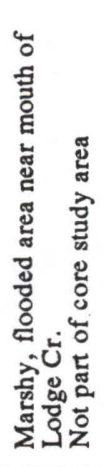 \\
\hline ऊัّ้ & - & $N$ & $m$ & $\vec{\nabla}$ & $n$ & 0 & $\Sigma$ & $r$ & $\stackrel{u}{r}$ & $\infty$ & $a$ \\
\hline
\end{tabular}




\section{DEMOGRAPHIC CHARACTERISTICS}

Our preliminary assessment is that the population in the study area has declined approximately $80 \%$ compared to the 1950 s population. Frogs in the 1990 s reproduced at two of the three former breeding sites within the study area, but numbers of egg clusters at these two sites have declined $70-86 \%$ relative to the 1950 s.

Turner's historical study used data from the capture and recapture of individuals over a period of three years to estimate population size, sex ratios, age distributions, survival, and growth rates. To obtain data for similar analyses of the 1993 population, we conducted an intensive capture/recapture effort of frogs in the core study as defined by Turner, and, less intensively, in Lodge Creek downstream of the study area to Yellowstone Lake. We made a total of 892 captures during the active season. Many frogs were recaptured at least once; others were recaptured on several occasions. We also marked a number of metamorphosing larvae. Results are tabulated in Table 2.

Our estimate of the population in the study area in 1993 indicates a decline of approximately $80 \%$ compared to 1953 . Turner (1960) estimated a 1953 population size of $1559 \pm 132$ frogs $(\hat{\mathrm{N}} \pm$ SD). Our 1993 estimate of the population size within the same area is $300 \pm 22$ frogs. Both estimates are based on the Lincoln-Petersen method, which uses a ratio of marked to total animals to estimate a total population. The two estimates are not strictly comparable; Turner's estimate was based on two active seasons of capture/recapture data, while ours is based on a single active season. In addition, 1993 was abnormally cool, possibly resulting in frogs being less active and therefore less likely to be observed and captured. There is some corroborating evidence of a decline; Turner revisited the site in 1991 and was struck by the relative scarcity of frogs as compared to the 1950s. Also, in 1991, we conducted mark/recapture of frogs in upper Lodge Creek (a large portion of the study area), and from that data we estimated a population of $245( \pm 30)$ frogs. We think that the population has declined significantly since the 1950 s.

Reproduction occurred in 1993 at two breeding pools identified by Turner in the 1950s, pool 1 in the meadow and pool 3 in the forest. A third breeding site formerly used by frogs in the area is no longer in existence. In 1955, Turner (1957) documented 26 egg clusters at pool 1 and 25 at pool 3. By contrast, we found three egg clusters at pool 1 and twelve at pool 3 in 1991 (Peterson et al. 1992), and in 1993 we found three egg clusters at pool 1 and four at pool 3 .

Because spotted frogs in Y.NP are slowgrowing and long-lived, the size or age class structure of the population in a given year reflects reproductive successes and mortality rates of several past years (Turner 1957). Further analyses of our 1991 and 1993 data, in addition to data collected in 1994, may provide more insights into the nature of the population decline.

Table 2. Summary of Capture/Recapture Data, 1993

\begin{tabular}{||l|l||}
\hline \multicolumn{1}{|c||}{ Category } & $\begin{array}{l}\text { Number of } \\
\text { Frogs }\end{array}$ \\
\hline Frogs marked, total & 564 \\
\hline Frogs recaptured, total* & 214 \\
\hline Adult and juvenile frogs marked, core study area & 238 \\
\hline Adult and juvenile frogs recaptured, core study area* & 161 \\
\hline Metamorphosing larvae marked in breeding ponds & 190 \\
\hline
\end{tabular}

*This category includes frogs captured at least one time in 1993; it does not include multiple recaptures of the same frogs. 


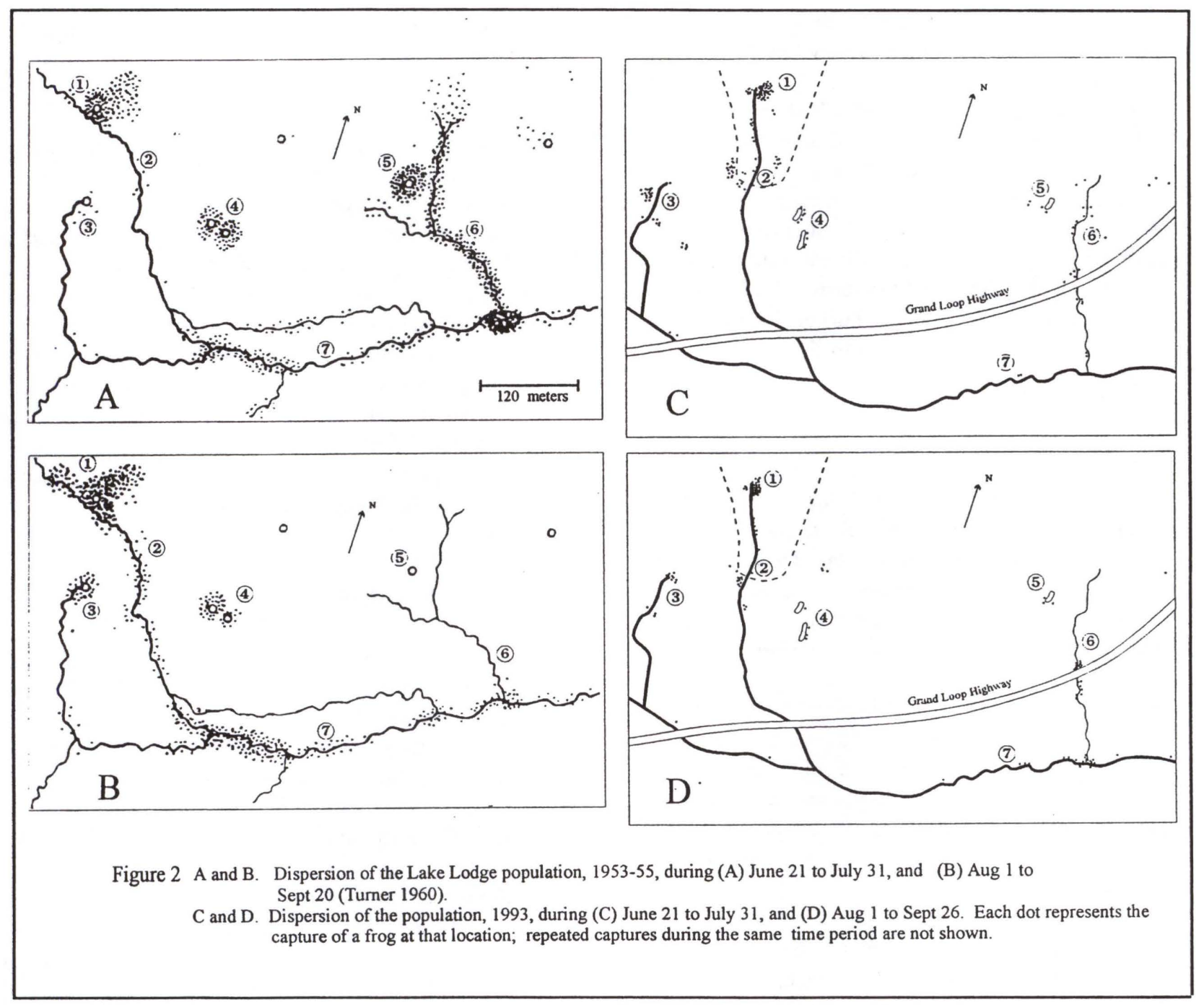

\section{DISTRIBUTION}

In 1993, we found frogs at many of the locations identified by Turner in the 1950s. However, overall distribution of frogs in the study area appears to have changed in some ways. While all occupied habitat sites within the study area have fewer frogs than they did in the 1950 s, there also are differences in the proportions of frogs at these sites compared to the 1950s. The area along Lodge Creek south of the highway has proportionately fewer frogs, and Lodge Creek upstream of the highway has proportionately more frogs than in the 1950s.

Turner plotted all points of capture and recapture for a series of 1144 frogs on a set of maps representing three periods of the summer over the three years of the study. The last two periods (June 21-July 31, and Aug 1-Sept 20) are reproduced in Fig. 2, A and B. Similarly, we mapped locations of frogs captured in 1993 (Fig. 2, C and D). To estimate and compare differences in relative use of the habitat areas for 1953 and 1993, we averaged the June-July and August-September captures and calculated proportions of frogs using the various habitat areas. These numbers are given as percents in Table 2. Validity of the comparisons is limited by our inability to control for error introduced by unequal sampling effort. If, however, the dispersion patterns are generally representative, some contrasts between the two data sets are so large as to indicate real differences rather than differences in sampling. 
The data suggest two important conclusions: (1) Lodge Creek south of the highway (areas 7 and 7C in Table 2) supports far fewer frogs, proportionately as well as absolutely, than it did historically. While Turner made $36 \%$ of the captures along this section of Lodge Creek, we found only 7\%; and (2) the headwaters area of Lodge Creek and adjacent wetlands (areas 1, 2, and 3 in Table 2) remain extremely important, potentially even more important than they were historically in terms of the persistence of this population. While Turner found less than $30 \%$ of the 1950 s population in this area, we found over $73 \%$.

\section{MOVEMENTS}

Both the 1950s and the 1990s data sets reveal that some individual frogs move quite extensively within the study area. Despite our small sample size, we found many of the same types of movements that Turner described. An important exception is the lack of movements in 1993 connecting the southwestern corner of the area (Lodge Creek south of the highway) to the far eastern end (Pool 1 and meadows). Movements among these areas require crossing of the highway. Not all movements across the highway are prevented. However, frogs managed to get across the highway in the vicinity of the ephemeral drainage in the eastern study area.

Turner found that movements of individual frogs within the study area connected key habitat features. Frogs moved among areas at the head of Lodge Creek, pool 1, pools 3 and 4 , the eastern meadow and ephemeral stream, and the Lodge Creek drainage below the confluence of the east and middle forks. In the 1950s, even the farthest corners of the study area (western Lodge Creek and the eastern meadows) were linked by movements taking place during one season or over a period of several seasons. Frogs moved overland to reach the pools, but relied on streams and intermittent stream channels as movement corridors in late summer. In 1993, we also found that frog movements connected many of the habitat features of the core study area (Fig. 3). From capture/recapture and telemetry data, we found 15 frogs that made movements within the wetlands around the headwaters of the two forks of Lodge creek, and 23 frogs that moved to or from habitat areas at the pools, meadow, Lodge Creek, and Lodge Creek headwaters. We found no instances of frogs moving between the core study area and the lower portion of Lodge Creek near Yellowstone Lake.

Comparing movements of the 1950s and the 1990s, we found 8 of the 15 movement patterns described by Turner (Fig. 3). Of the 7 that are not represented in the 1993 data, 6 movements involve Lodge Creek south of the highway (area 7east and 7west in Fig. 3). We found, however, that frogs continue to use the ephemeral drainage to move between the eastern meadow and Lodge Creek even though the highway bisects these two areas. At least 8 frogs managed to move across the highway (6 downstream and 2 upstream) in this area. One telemetered frog apparently crossed the road surface, but it is possible that some frogs use the large culvert under the highway as a passage.

\section{- SUMMARY}

A large spotted frog population occupied streams and seasonally wet areas in the vicinity of Lake Lodge during the 1950s. Demographic characteristics, spatial distribution, and movement patterns of the 1950 s population were documented by Frederick B. Turner. We are comparing data from the 1950s with data that we are collecting in 1990s to determine how the frog population and its use of habitat has changed. Spotted frogs have persisted in the area despite development of a water pumping system at the head of Lodge Creek and the relocation of Grand Loop Highway, which now bisects the former study area. Our preliminary work indicates that population size has declined by about $80 \%$, from approximately 1500 frogs to approxmiately 300 frogs. Numbers of egg clusters deposited in the 1990s declined $70 \%$ in 1991 and $86 \%$ in 1993, compared to 1955. Most of the habitat features (pools, streams, boggy areas) identified during the former study still exist and remain occupied by frogs. There are, however, changes in the distribution of frogs among these areas. The head of Lodge Creek has changed the most in terms of hydrology and vegetation, and while it appears to support fewer frogs than it did historically, it now supports a higher proportion of the population. In contrast, Lodge Creek south of the highway that now bisects the former study area shows a sharp decline in both absolute and proportional use, indicating a reduction of effective habitat compared to that occupied by the 1950 s population. 
Figure 3. Movements among key habitat areas.

Numbers refer to habitat areas identified on Figures $1 \mathrm{~B}$ and 2.

$+1+$ refers to $1950 \mathrm{~s} / 1993$, e.g. $+/$ - indicates that movements were found between these areas in the $1950 \mathrm{~s}$ but not in 1993. Only movements occurring within one season were included from the 1950s data.

\begin{tabular}{||l|l|l|l|l|l|l||}
\hline \hline Areas & 3 & 4 & 5 & 6 & 7 east & 7 west \\
\hline $1 \& 2$ & $+1+$ & $+1+$ & $+1+$ & $+1+$ & $+1-$ & $+1-$ \\
\hline 3 & & $+1-$ & $-1-$ & $-1-$ & $-1-$ & $-1+$ \\
\hline 4 & & & $+1+$ & $+1+$ & $-1-$ & $+1-$ \\
\hline 5 & & & & $+1+$ & $+1-$ & $+1-$ \\
\hline 6 & & & & & $+1+$ & $+1-$ \\
\hline
\end{tabular}

Movements of frogs observed in 1993 indicate that dispersal among habitat areas is similar to the $1950 \mathrm{~s}$, with the exception of dispersal between Lodge Creek south of the highway and the far eastern side of the study area. We are in the process of comparing data sets from the 1950 s and the 1990 s to determine more precisely the nature of changes in demographic characteristics, distribution, dispersal, and habitat.

\section{IMPLICATIONS AND FUTURE WORK}

The importance of habitat diversity and metapopulation dynamics for the persistence of animal populations have been emphasized by theoretical and empirical research in conservation biology (Terborgh 1974, Diamond 1975, Soule and Wilcox 1980, Wilcox 1980, Merriam 1984, Pulliam 1988). The Lodge Creek spotted frog population provides a case study potentially capable of revealing how these concepts may apply to amphibians. It is particularly valuable because of the existence of detailed, historical data. We hypothesize that the persistence and robustness of this spotted frog population is linked closely to its access and use of diverse kinds of habitat: seasonally wet meadow areas, ephemeral streams, breeding pools, springs, and permanent streams. In addition, emigration from other breeding populations in the area may contribute to population persistence. We further hypothesize that fragmentation caused by highway construction and habitat loss may be important factors in explaining the decline of this population. In 1994, we will continue to investigate and develop these hypotheses through continued mark/recapture and telemetry of frogs in the core study area, close monitoring of frog movements among the key habitat areas, and comparisons of historical and current data on distribution, dispersal, and demographics. We also will expand mark/recapture efforts to drainages and wetland areas north and south of the core study area, and we will continue to study frogs in lower Lodge Creek to determine if and how the population may be linked to others in the area.

\section{$\checkmark \quad$ ACKNOWLEDGMENTS}

This research was supported mainly by funding from the University of Wyoming National Park Service Research Center. We also received financial support from the Declining Amphibian Populations Task Force, the American Natural History Museum Theodore Roosevelt Memorial Fund, and Idaho State University. In addition, matching funds were provided by the National Fish and Wildlife Foundation. We are very grateful for the assistance and cooperation of numerous people at YNP, including Stu Coleman, Bob Lindstrom, Lee Whittlesey, Jennifer Whipple, John Lounsbury and the Lake Ranger District staff. We are especially thankful for Dan Reinhart's enthusiastic support and the involvement of the Resource Management program at Lake Ranger District in this project. For help with early stages of the project in 1991, we appreciate the valuable involvement of Fred Turner, 
Denise Culver, Roger Andrascik, and Ted Koch. We acknowledge and thank Paul Bartelt for his efforts and important achievements in the development of amphibian telemetry techniques, and for his help with GPS mapping. Merlin Hare's expertise and work on computer graphics for the study site maps is greatly appreciated. We also thank Chris Askey for his assistance in the field.

\section{- LITERATURE CITED}

Adler, K. 1992. Introduction. In: K. Adler (ed), Herpetology. Proceedings of the First World Congress of Herpetology, pp 2-5. Society for the Study of Amphibians and Reptiles. Oxford, Ohio.

Beiswenger, R.E. 1986. An endangered species, the Wyoming Toad Bufo hemiophrys baxteri the importance of an early warning system. Biol Cons 37:59-71.

Corn, P.S. and R.B. Bury. 1989. Logging in western Oregon: responses of headwater habitats and stream amphibians. For. Ecol. \& Mgmt. 29:39-57.

Corn, P.S. and J.C. Fogelman. 1984. Extinction of montane populations of the Northern Leopard Frog Rana pipiens in Colorado. J. of Herpetology 18:147-152.

Corn, P.S., and F.A. Vertucci. 1992. Descriptive risk assessment of the effects of acidic deposition on Rocky Mountain amphibians. J. of Herpetology 26:361-368.

Diamond, J.M. 1975. The island dilemma: lesson of modern biogeographic studies for the design of natural reserves. Biol. Conserv. 7:129146.

Gibbons, J.W. 1988. The management of amphibians, reptiles and small mammals in North America: the need for an environmental attitude adjustment. In: R.C. Szaro, K.E. Severson, and D.R. Patton, eds. Management of Amphibians, Reptiles, and Small Mammals in North America.
Proceedings of the Symposium, pp 4-10. USDA Forest Service GTR-RM-166. Rocky Mtn For \& Range Exp Stn. Ft Collins, CO. $458 \mathrm{pp}$.

Groom M.J. and N. Schumaker. 1993. Evaluating landscape change: patterns of worldwide deforestation and local fragmentation. In P.M. Kareiva, J.G. Kingsolver, and R.B. Huey eds. Biotic Interactions and Global Change, pp 24-44. Sinauer Assc Inc. Sunderland, MA. 559 pp.

Harte, J. and E. Hoffman. 1989. Possible effects of acidic deposition of a Rocky Mountain population of the tiger salamander Ambystoma tigrinum. Conservation Biology 3(2):149-158.

Langton, T.E.S. 1989. Amphibians and Roads. Proceedings of the Toad Tunnel Conference. ACO Polymer Products, Shefford, England. 202 pp.

McAllister, K.R. and B. Leonard. 1990. 1989 Progress Report - Past distribution and current status of the spotted frog in western Washington. Washington Department of Wildlife, Wildlife Management, Nongame Program.

Merriam, G. 1984. Connectivity: a fundamental ecological characteristic of landscape pattern. In J. Brandt and P. Agger (eds) Methodology in Landscape Ecological Research and Planning, pp 5-15. Roskilde, Denmark.

Pechmann, J.K.H., D.E. Scott, R.D. Semlitsch, J.P. Caldwell, L.J. Vitt, and J.W. Gibbons. 1991. Declining amphibian populations: the problem of separating human impacts from natural fluctuations. Science 253:892-895.

Peterson, C.R., E.D. Koch, and P.S. Corn. 1992. Monitoring amphibian populations in Yellowstone and Grand Teton National Parks. Final report to the UW-NPS Research Center. 
Pulliam, H.R. 1988. Sources, sinks, and population regulation. Am Nat 132:652-661.

Sinsch, U. 1989. Migratory behavior of the common toad Bufo bufo and the natterjack toad Bufo calamita. In: T.E.S.Langton (ed), Amphibians and Roads. Proceedings of the Toad Tunnel Conference, pp 113-126. ACO Polymer Products, Shefford, England. 202 pp.

Sjogren, P. 1991. Extinction and isolation gradients in metapopulations: the case of the pool frog Rana lessonae. Biol $\mathrm{J}$ of the Linnean Soc 42:135-147.

Soule, M.E. and B.A. Wilcox. 1980. Conservation Biology. Sunderland, MA: Sinauer Associates.

Terborgh, J. 1974. Preservation of natural diversity: the problem of extinction prone species. BioScience 24:715-722.

Turner F.B. 1957. The ecology and morphology of Rana pretiosa pretiosa in Yellowstone Park, Wyoming. PhD dissertation, University of California. 210 pp.

Turner, F.B. 1958. Life history of the western spotted frog in Yellowstone National Park. Herpetologica 14:96-100.

Turner, F.B. 1960. Population structure and dynamics of the western spotted frog, Rana p. pretiosa Baird \& Girard, in Yellowstone Park, Wyoming. Ecol. Monographs 30(3):251-278.
USDI Fish and Wildlife Service. 1993. Endangered and threatened wildlife and plants; finding on petition to list the spotted frog (50 CFR Part 17). Fed. Reg. 58(87):27260-27263.

Waichman, A.V. 1992. An alphanumeric code for toe clipping amphibians and reptiles. Herp Rev 23(1):19-21.

Wake, D. B. 1991. Declining amphibian populations. Science 253:860.

Wake, D. B. and H. Morowitz. 1990. Declining amphibian populations--a global phenomena? Workshop sponsored by Board on Biology, National Research Council, Irvine, CA.

Wilcox, B.A. 1980. Insular ecology and conservation. In Soule, M.E. and B.A. Wilcox, eds., Conservation Biology: An Evolutionary-Ecological Perspective. Sunderland, MA: Sinauer Associates, pp 95118.

Wyman, R.L. 1990. What's happening to the amphibians? Cons Bio 4:350-352.

Wyman, R.L. and D. Hawksley-Lescault. 1988. Soil acidity affects distribution, behavior, and physiology of the salamander Plethodon cinereus. Ecology 68:1819-1827. 